\section{OPEn OACCEss}

DOI: $10.25040 /$ ntsh2021.01.01

Для листування:

вул. Пекарська 69, м. Львів, Україна, 79010 Е-пошта: ozayachkivska@gmail.com Orest.Chevtchik@gmail.com

Стаття надійшла: 03.06.2021

Прийнята до друку: 16.06.2021

Опублікована онлайн: 29.06.2021

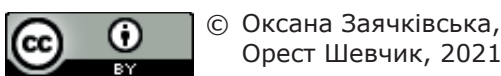

\section{ORCID IDs}

Oksana Zayachkivska

https://orcid.org/0000-0002-4309-2473

Orest Chevtchik

https://orcid.org/0000-0003-3325-4288

\section{Особистий внесок авторів:}

Концепція: О. Заячківська, О. Шевчик.

Написання статті: О. Заячківська,

О. Шевчик

Фінансування. Підготовка цього огляду не потребувала фінансування.

\section{Можливості для розвитку науки під час пандемії COVID-19}

\author{
Оксана Заячківська ${ }^{1}$, Орест Шевчик² \\ ${ }^{1}$ Львівський національний медичний університет імені \\ Данила Галицького, Львів, Україна, \\ ${ }^{2}$ Відділ кардіоторакальної хірургії Королівського шпиталю \\ Единбурга, м. Единбург, Велика Британія
}

\section{Дорогий читачу!}

21-й рік XXI століття увійде в історію як межа, що поділила наше життя: на добу пандемії коронавірусної хвороби (COVID-19) і добу після COVID-19. Саме зусилля медичних наукових академічних інституцій і жертовна високопрофесійна робота лікарів світу продемонстрували високу готовність до подолання сучасних викликів пандемії, що охопила все людство. Світ отримав нові можливості у розвитку науки для розуміння стратегії боротьби з «чумою» XXI століття. Насамперед це створення специфічної профілактики COVID-19 у рекордно короткі терміни: 10 січня 2020 року з'явилась інформація про секвенування вірусу SARS-CoV-2 (також відомий як 2019-nCoV), а від 11 грудня 2020 року розпочато застосування вакцинації проти COVID-19 серед медичних працівників у США. На сьогодні вакцинацію проти SARS-CoV-2 вже отримали більше 2-х мільярдів осіб [1]. У Великій Британії вже упродовж 25-ти днів не зареєстровано жодного випадку смерті (на 03.06.2021), хоча зміни у геномі SARS-CoV-2 і поява нових штамів вірусу продовжуються, та й повідомлення з регіонів з високим рівнем захворюваності, як Індія, надалі тривожні. Пандемія вірусу SARS-CoV-2, який на сьогодні заразив понад 171 мільйон осіб і вбив більше 3,5 мільйонів, стала грандіозним випробуванням для новітніх вакцин, що відрізняються від попередніх. Як ніколи важливими стають правильна організація і проведення клінічних досліджень. Саме цій темі присвячена стаття Андрія Черкаса [2]. Створені та апробовані у клінічних дослідженнях вакцини «Pfizer», «Moderna», «AstraZeneca», «Johnson-Johnson» стали можливим завдяки результатам фундаментальних досліджень Каталін Каріко, Дрю Вайсмана, що були розпочаті майже 30 років тому і започаткували п'яту еру вакцинації [3; 4].

Цей клас вакцин не містить вірусних білків, адже ці вакцини використовують мРНК, ДНК або вірусні вектори, які дають інструкції клітинам про те, як зробити такі білки. Історія створення цієї біотехнології векторних вакцин, яка багата на факти зневажання, відхилення та замовчування [5-7], проте гідна присудження найпрестижнішої міжнародної премії за видатні наукові дослідження [8], має багато спільного з історією відкриття X-променів, яке здійснив Іван Пулюй. Саме його відкриття стало передумовою для створення сучасних високотехнологічних методів променевої діагностики, які у наш час лікарі застосовують як основний інструмент для підтвердження ускладнених форм COVID-19. Цій темі у нашому випуску присвячена стаття Уляни Підвальної, Романа Пляцка, Василя Лончини [9] і титульна сторінка цього числа, на якій колаж Івана Дзіся, що уособлює взаємопов'язаність минулого та сьогодення, історії та сучасності, важливості променевої діагностики для COVID-19. Запрошуємо читачів ознайомитись з оглядом Фатеме Таваколі Фар, Ехсана Амірі-Ардекані, що дозволить читачам розширити знання про патогенність SARS-COV-2 і лікування COVID-19 [10]. 


\title{
Opportunities for Science Growth amidst the COVID-19 Pandemic
}

\author{
Oksana Zayachkivska ${ }^{1}$, Orest Chevtchik² \\ ${ }^{1}$ Danylo Halytsky Lviv National Medical University, Lviv, Ukraine \\ 2 Department Cardiothoracic Surgery, Royal Infirmary of \\ Edinburgh, Edinburgh, UK
}

\section{Dear reader!}

The 21st year of the 21st century will go down in history as the boundary that divided the coronavirus (COVID-19) pandemic and post-pandemic world. It is the efforts of medical academic institutions and the dedicated medical professionals all around the world that have demonstrated a high readiness to overcome the modern challenges of the pandemic that has engulfed all the humanity. The world has received a new vector in the development of science to understand the strategy to combat the «plague» of the 21st century. First, it is the creation of specific prevention of COVID-19 at a record pace: on January 10, 2020, the information on the sequencing of SARS-CoV-2 virus (also known as 2019-nCoV) was received, and on December 11, 2020, vaccination against COVID-19 started among healthcare professionals in the United States. Currently, more than 2 billion people worldwide have been vaccinated against SARS-CoV-2 [1]. No deaths have been reported in the UK for 25 days (as of June 3, 2021), nevertheless changes in the SARS-CoV-2 genome and the emergence of new virus strains continue, and reports from high-incidence regions such as India are still alarming. The pandemic of the SARS-CoV-2 virus, which as of today has infected more than 171 million and killed more than 3.5 million people globally, has been a major test for newer vaccines that differ from the previous ones. The organization and conduct of clinical research are becoming more important than ever. The article by Andriy Cherkas is dedicated to this topic [2]. Pfizer, Moderna, AstraZeneca and Johnson-Johnson vaccines developed and tested in clinical trials were made possible following the results of fundamental research by Katalin Karikó and Drew Weisman, which began almost 30 years ago [2] and ushered in the fifth era of vaccination $[3,4]$.

This class of vaccines does not contain viral proteins, as these vaccines use mRNA, DNA, or viral vectors that instruct cells on how to make such proteins. The history of this biotechnology of vector vaccines, which is rich in facts of contempt, rejection and silence [5-7], but worthy of the most prestigious international award for outstanding research [8], has much in common with the history of the discovery of X-rays by Ivan Puluj. His discovery was the source for the creation of modern high-tech methods of radiological diagnostics, which are used by doctors today as the main tool for confirming complicated forms of COVID-19. This topic is the subject of the article by Uliana Pidvalna, Roman Plyatsko, Vassyl Lonchyna [9] and the title page of this issue, featuring a collage by Ivan Dzis which embodies the interconnection between the past and the present, history and contemporary times and the importance of radiation diagnostics for COVID-19.

We welcome our readers to read the review by Fateme Tavakoli Far, Ehsan Amiri-Ardekani, which will allow readers to expand their knowledge about the pathogenicity of SARS-COV-2 and the treatment of COVID-19 [10]. In the «Topical» section, we draw readers' attention to important topics of today, which are articles by Surya Kannan, Johan Ericsson, Nazariy Souchelnytskyi, 


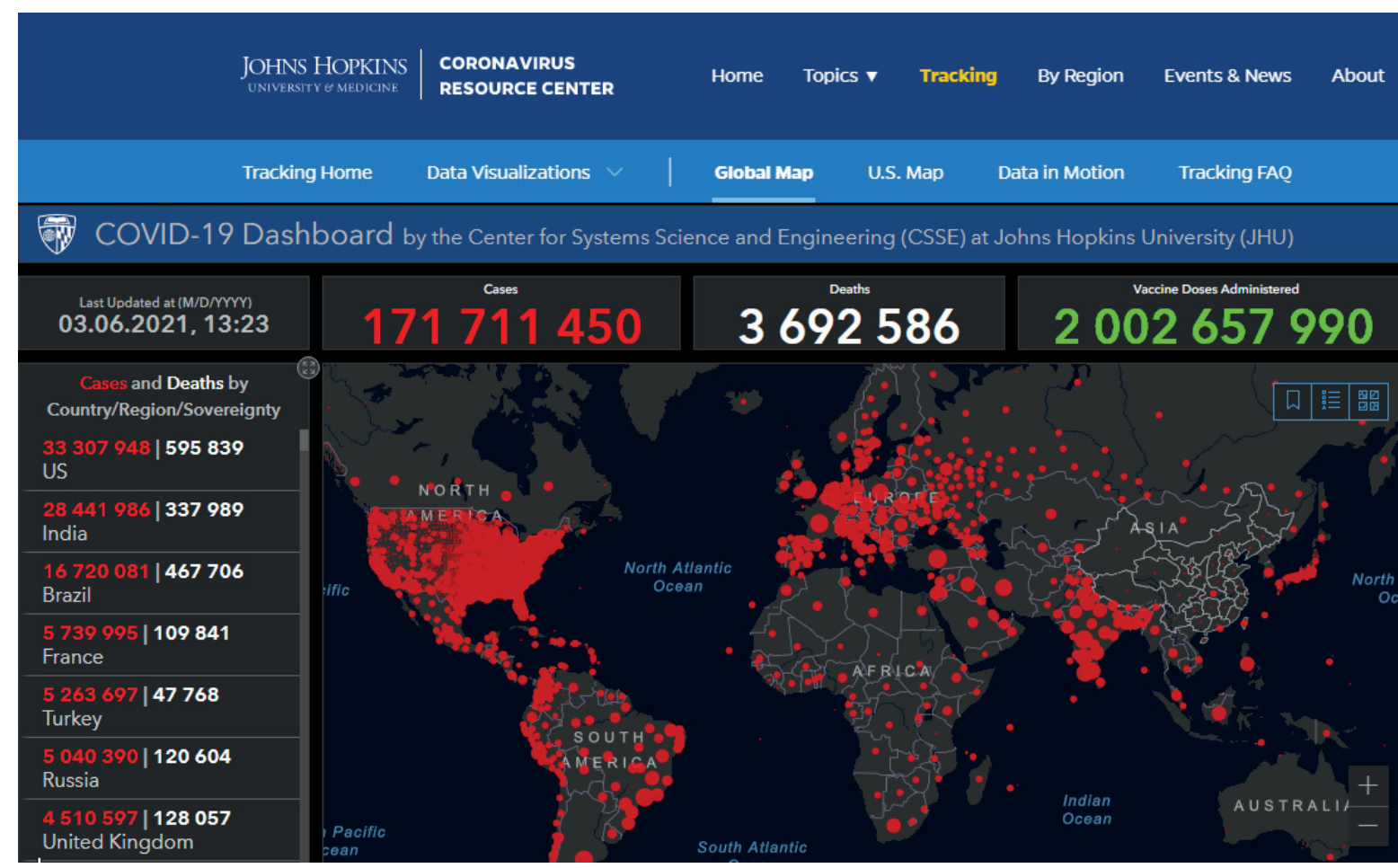

Рис. 1. Інформація про вакцинацію проти SARS-CoV-2 і поширення пандемії COVID-19 у світі (за даними Університету Джона Гопкінса (Меріленд, США) на 03.06.2021 [1])

У розділі «Актуально» звертаємо увагу читачів на важливі теми сьогодення, які представляють статті Сур'я Каннан, Йохана Еріксона, Назарія Сушельницького, Сергія Сушельницького про сучасні новітні діагностичні методи SARS-COV-2 у слині [11] і наукової групи Олександра Фільца і Альфреда Прітца про тривалі наслідки COVID-19, відомі як постковідний синдром (англ.: Post-COVID-19 syndrome) або лонг-COVID (англ.: Long COVID) [12; 13].

Другою прогресивною можливістю для розвитку сучасного суспільства під час пандемії COVID-19 стало широке використання дистанційних інформаційних комунікацій, які перетворились в ефективний інструмент для глобального об'єднання науковців і лікарів у розбудові віртуального міжнародного співробітництва. Важко уявити, як відбулась би пандемія COVID-19 без відкриття World Wide Web Тім Барнерс-Лі 1989 року, що кардинально змінило світ, об'єднавши його у єдиний «файлообмінний» простір, який втратив географічні кордони, а наш час став реальною формацією для об'єднання, спілкування і людських стосунків та реалізації задумів і проєктів [14]. В умовах карантину рутиною стали віртуальні міжнародні дискусії та обміни знань між колегами зі всього світу. Прикладом такої співпраці $\epsilon$ робота редколегії нашого журналу, коли разом 3 колегами з-за океану, європейських країн, Великої Британії, Індії у 2021 році відбулася серія вебінарів, що творять ефективну міжнародну медіаплатформу для навчання молодих науковців і лікарів не лише з України, а й інших країн світу. Адже це важливо отримати певні наративи з уст наукових лідерів, перших осіб та експертів, як Джеффрі Білл (США), Армен Гаспарян (Велика Британія), Мохамед Абдоллагі (Іран), Латіка Гупта (Індія), Дурга Прасанна Місра (Індія), Сречко Гайович (Хорватія) та інші про актуальні проблеми медицини й науки сьогодення [15].

Важливо зазначити ще одну можливість для розвитку науки, з огляду на зміни світу в час пандемії, спричиненої SARS-COV-2, та рекомендації ВОO3 про запровадження запобіжних заходів відповідно до політики «залишатися вдома», - це «занурення» кожного в соціальні медіа як новітні джерела швидкого суспільного інформування. Сьогодні важко уявити соціальні медіа без наукових медичних медіа, адже це дає шанс з'ясувати проблему чи порівняти 


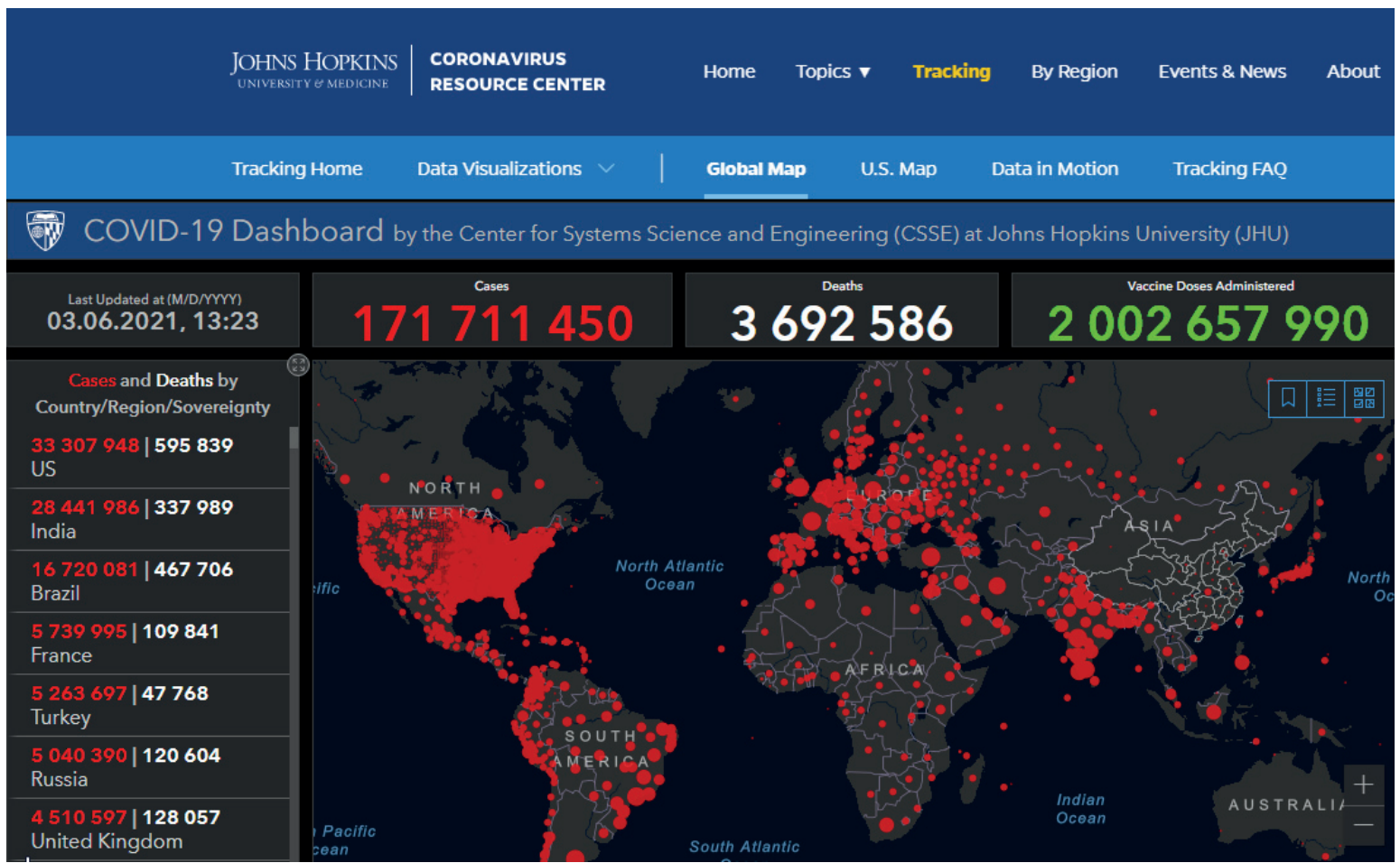

Figure 1. Information on vaccination against SARS-CoV-2 and COVID-19 pandemic spread in the World and Ukraine (by Johns Hopkins University (Maryland, USA), June 3, 2021 [1])

Serhiy Souchelnytsky on modern latest diagnostic methods of SARS-COV-2 in saliva [11] and the scientific group of Alexander Filz and Alfred Pritz on the long-term effects of COVID-19, known as post-COVID-19 syndrome or Long COVID $[12,13]$.

The second progressive opportunity for the development of modern society during the COVID-19 pandemic was the widespread use of remote information communications, which became an effective tool for the global unification of scientists and physicians and the development of virtual international cooperation. It is hard to imagine how the response to the COVID-19 pandemic would have happened without the opening of the World Wide Web by Tim Berners-Lee in 1989, which changed the world drastically into a single «file-sharing» space that lost geographical boundaries and became a real tool for unification, communication and human relations and implementation of plans and projects [14]. In the conditions of quarantine, virtual international discussions and knowledge exchanges between colleagues from around the world have become routine. Such cooperation can be exemplified by the work of our journal's editorial board, when in 2021, we held a series of webinars together with colleagues from overseas, European countries, Great Britain and India that created an effective international media platform for training young scientists and doctors not only from Ukraine, but other countries too. After all, it is important to get certain narratives about current issues of medicine and science first-hand from scientific leaders, experts like Jeffrey Beall (USA), Armen Gasparyan (UK), Mohammad Abdollahi (Iran), Latika Gupta (India), Durga Prasanna Misra (India), Srećko Gajović (Croatia) and others [15].

Another important opportunity for science to evolve in light of the changing world of the SARSCOV-2 pandemic and WHO's recommendation to take precautions following the «stay at home» policy was to «immerse» everyone in social media - the latest sources of rapid public information. Today, it is difficult to imagine social media without scientific medical media, as this gives a chance to clarify the problem or compare the situation, for example, in Ukraine and the UK, in one click. We invite you to read a study of their significance during the COVID-19 pandemic in the lives of scientists and physicians in Eastern Europe in an article by our social media editors [16]. 
ситуацію, наприклад, в Україні та Великій Британії, за кілька кліків. Дослідження їхнього значення під час пандемії COVID-19 у житті науковців і медиків Східної Європи запрошуємо прочитати у статті наших редакторів соціальних мереж [16].

Проте варто пам'ятати про побічні ефекти такого стилю життя, що опосередковано чи безпосередньо сприяє хронічному стресу, пов'язаному з COVID-19 [17; 18], це підтверджують результати досліджень самопочуття студентів-медиків Львівського національного медичного університету імені Данила Галицького [19]. Тож нехай наступною можливістю сучасного життя в добу після COVID-19 стане звільнення з гачка стресу важких думок і почуттів, пов'язаних з COVID-19, і заземлення відповідно до наших цінностей [20] і рекомендацій Джонатана Форда Г'юза про щоденні три важливі звички для лікарів: спілкуватись з природою, практикувати йогу і вести журнал турботи про себе [21].

Сподіваємось, що нове число нашого журналу буде цікавим для Вас.

\section{References}

1. John Hopkins Coronavirus Resource Center. Available at: https://coronavirus.jhu.edu/map.html; last accessed June 3, 2021.

2. Cherkas A. Research involving human subjects in Ukraine: How to leverage arising opportunities? Proc Shevchenko Sci Soc Med Sci 2021; 64 (1): 10-15.

3. Desmond A, Offit PA. On the Shoulders of Giants - From Jenner's Cowpox to mRNA Covid Vaccines. New England Journal of Medicine. 2021 Mar 25; 384 (12): 1081-3.

4. Kariko K, Weissman D. Naturally occurring nucleoside modifications suppress the immunostimulatory activity of RNA: implication for therapeutic RNA development. Current Opinion in Drug Discovery and Development. 2007 Sep 1; 10(5): 523.

5. Hargittai, I., Hargittai, M. Our science and the Covid-19 pandemic - Katalin Karikó's research idea and her perseverance. Struct Chem (2021). https://doi.org/10.1007/s11224-021-01797-9

6. Garade D. The story of mRNA: How a once-dismissed idea became a leading technology in the Covid vaccine race. Stat. Retrieved. 2020 Nov;16. https://www.statnews.com/2020/11/10/the-story-ofmrna-how-a-once-dismissed-idea-became-a-leading-technology-in-the-covid-vaccine-race/

7. Gelles D. The husband-and-wife team behind the leading vaccine to solve covid-19. New York Times. https://www. nytimes. com/2020/11/10/business/biontech-covid-vaccine. html. Accessed. 2021 Mar; 3. https://www.nytimes.com/2020/11/10/business/biontech-covid-vaccine.html

8. Szabo S (2020), private communication by e-mail of December 30.

9. Pidvalna U, Plyatsko R, Lonchyna V. Ivan Puluj and the discovery of X-rays. Proc Shevchenko Sci Soc Med Sci 2021; 64 (1): 180-190.

10. Far FT, Amiri-Ardekani E. Spike protein and involved proteases in SARS-COV-2 pathogenicity and treatment. Proc Shevchenko Sci Soc Med Sci 2021; 64 (1): 52-61.

11. Kannan S, Ericsson J, Souchelnytskyi N, Souchelnytskyi S. A protocol for the detection of genetic markers in saliva by polymerase chain reaction without a nucleic acid purification step: examples of SARS-COV-2 and GAPDH markers

12. Classification of Diseases (ICD)/Emergency use ICD codes for COVID-19 disease outbreak. https:// cdn.who.int/media/docs/default-source/classification/icd/covid-19/covid-19-coding-updates-3-4combined.pdf?sfvrsn=39197c91_3

13. Filts O, Fitkalo O, Lyzak O, Myshakivska O, Bereziuk O, Samsonova L, Pritz A. Toward a cohesive clinical interpretation of mental disorders in SARS -CoV-2 pandemic: an expert opinion. Proc Shevchenko Sci Soc Med Sci 2021; 64 (1): 155-160.

14. Berners-Lee T, Cailliau R, Groff JF, Pollermann B. World-Wide Web: the information universe. Internet Research. 1992.

15. Telishevska U. Advances in Science Editing and Communication (part 2). Proc Shevchenko Sci Soc Med Sci 2021; 64 (1): 30-35.

16. Zimba O, Pavlovskyy Y, Danylyak O, Humenetska N, Kowalska M, Pidvalna U. Social media use among researchers from Eastern Europe during the COVID-19 pandemic: a cross-sectional survey study. Proc Shevchenko Sci Soc Med Sci 2021; 64 (1): 204-208.

17. Taylor S, Landry CA, Paluszek MM, Fergus TA, McKay D, Asmundson G]. Development and initial validation of the COVID Stress Scales. Journal of Anxiety Disorders. 2020 May 1;72:102232. 
However, it is worth remembering the side effects of such a lifestyle that indirectly or directly contributes to chronic stress associated with COVID-19 $[17,18]$, which confirms the results of studies of the health of medical students of Lviv Danylo Halytsky National Medical University [19]. So, let the next opportunity for modern life in the post-COVID-19 include release from the stress hook of heavy thoughts and feelings associated with COVID-19, concentrating on our values [20] and Jonathan Ford Hughes' recommendations of three important daily habits for doctors: communicate with nature, practice yoga and keep a journal of self-care [21].

We hope you enjoy the issue.

18. Szabo S. COVID-19: New disease and chaos with panic, associated with stress. Proc Shevchenko Sci Soc Med Sci [Internet]. 2020 Apr.15 [cited 2021 Jun. 5]; 59 (1).

19. Muzyka I, Belka B, Ostrovska Yu, Zayachkivska O. Self-Perception of lifestyle and wellbeing changes associated to social distancing though COVID-19 pandemic among medical students (study in Lviv, Ukraine). Proc Shevchenko Sci Soc Med Sci 2021; 64 (1): 138-146.

20. World Health Organization. Doing what matters in times of stress: an illustrated guide. https://apps. who.int/iris/bitstream/handle/10665/339150/WHO-EURO-2021-361-40096-56774-ukr.pdf?fbclid =IwA R30ZF8RpjTAsJ2SGGApvD-tOuzpCKP9VQ7eDBuRZoxHtVszdV9y4PpToKc

21. Hughes JF. Doctors Should DoThese3Things Daily. MDLinx, April27, 2021. https://www.mdlinx.com/article/ doctors-should-do-these-3-things-daily/7K3dh1D5Iw0Q6wes6CMED1?show_order=1\&amp;utm _ campaign=malert_060321\&amp; tag=Morning\&amp;ipost_environment=m3usainc\&amp; $u t_{-}$ medium=email\&amp; utm_source=iPost\&amp;iqs=9z2znhpgd599otpjonoq0jv9hcqlt0b9gi4273kfhhg 